\section{British Biotech's MMPIs still alive}

On May 2, British Biotech (BBIOY; Oxford, UK) released some good news concerning its troubled phase III cancer trials of marimastat, a matrix metalloproteinase inhibitor (MMPI). Although interim analyses of marimastat against non-small-cell lung cancer were unfavorable-resulting in the termination of that trial—a study involving pancreatic cancer patients has shown positive results and will continue. In addition, a follow-up examination of a marimastat trial against gastric cancer that failed in January 1999 has revealed positive long-term survival results, particularly in patients who had previously received chemotherapy and those who did not have metastatic disease at diagnosis. Chief Financial Officer Tony Weir says these data offer a "glimmer of hope" after essentially writing off MMPIs as cancer therapeutics (Nat. Biotechnol. 19, 297, 2001). Shares were up $7 \%$ to $\$ 2.95$ the day after the news.

$A B$

\section{New Remune data analysis}

After reanalyzing data from its halted 1999 phase III trial, Immune Response (Carlsbad, CA) claims its experimental AIDS vaccine Remune is effective. The firm's share price rose $58 \%$ to $\$ 2.58$ on the announcement, which was published in the April issue of HIV Medicine (2, 68-77, 2001). The company says viral load was measured more frequently in a subset of 252 patients than in the original 2,527-patient study, allowing researchers to find immunization that wasn't apparent from analysis of the whole group. But lead researcher Joseph Kahn (University of California San Francisco; UCSF) says the new analysis of the study "is data-dredging. It's looking at information a number of ways until you find what you are looking for and reporting it as 'Eureka.' That's not science. That's marketing." Last September, Immune Response began legal proceedings against Kahn and co-researcher Stephen Lagakos (Harvard University, Cambridge, MA) for suppressing the subset data from their manuscript submission to JAMA (Nat. Biotechnol. 18, 1235, 2000). UCSF officials say the researchers and the firm agreed to seek binding arbitration in order to settle the disagreement.

EN

Business and Regulatory News Briefs written by Aaron Bouchie, Liz Fletcher, Jeffrey L. Fox, Sarah Greaves, Chris Morrison, and Eric Niiler.

\title{
EPA deputy administrator named
}

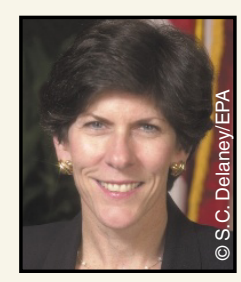

US President Bush has nominated Linda Fisher, a former vice president of government affairs at Monsanto (St. Louis, MO), to be deputy administrator of the US Environmental Protection Agency (EPA; Washington, DC). Fisher, who is an attorney, previously served at EPA between 1983 and 1993; in terms of biotechnology experience in the agency, she was appointed in 1989 to assistant administrator for pesticides and toxic substances during a period when several of the first genetically modified crops were under review. Many biotechnology critics quickly blasted her recent appointment on the part of the administration, claiming that Fisher will be pro-industry and pro-Monsanto. However, a company spokesperson and other industry representatives are equally quick to point out that Fisher will be under sharp scrutiny and explicit restrictions in any dealings with her former employer.

$J F$

\section{NME approval times increasing in the United States}

The US Food and Drug Administration (FDA; Rockville, MD) took about 16 months to approve new molecular entities (NMEs) in 2000, up from 12 months in 1999 according to the Center for Drug Evaluation and Research's (CDER; Rockville, MD) 2000 Report to the nation released on April 27. However, CDER Director Janet Woodcock attributes the increase in approval time to seven historically tardy products that all happened to be approved in 2000, dismissing the notion of a trend. However, in April, pending approvals of at least three NMEs under review at the FDA's Center for Biologic Evaluation and Research-Amgen's (Thousand Oaks, CA) new anemia drug Aranesp, Idec's (San Diego, CA) cancer monoclonal antibody Zevalin, and Genentech's (S. San Francisco, CA) asthma therapeutic Xolair - were pushed back a full quarter, significantly lowering investor earnings estimates. Such delays can result in lost profits and decreased patent protection time, which begins at filing. Meanwhile, FDA expects its plan to accept electronic submissions of any record by 2002, to increase efficiency of review times.

$A B$

\section{New allergenicity protocol}

An Ad Hoc Codex Intergovernmental Task Force on Foods Derived from Biotechnology met in late March to discuss a new report entitled Evaluation of allergenicity of genetically modified foods, which was put together by a joint expert consultation panel of the Food and Agriculture Organization of the United Nations (FAO) and the World Health Organization (WHO). The FAO/WHO panel has come up with a protocol to determine the allergenicity of food derived from recombinant plants (see flowchart). Allergen expert Steve Taylor of the University of Nebraska (Lincoln, NE) says although the protocol is thorough, it may pose some logistical problems for agbiotech firms looking to commercialize GM foods. In particular, he refers to the requirement to screen food with serum samples from patients who are allergic to an organism similar to that which the recombinant protein is derived (targeted serum screening). "Critics say... .who's going to have all this serum for people to use for the screening?" says Taylor. A working group is scheduled to meet in Canada at the end of this year to discuss practical implementation of the protocol, which World Trade Organization members will be required to follow if Codex adopts the task force's recommendation at its next meeting in 2003.

$A B$

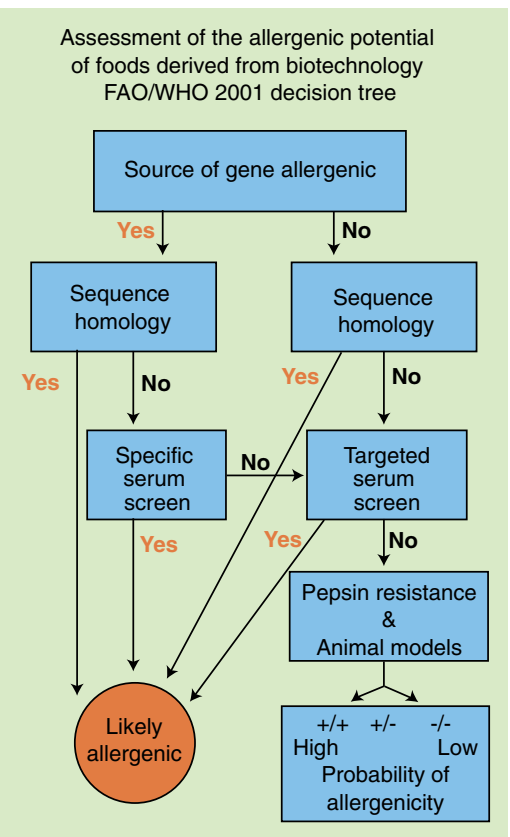

